\title{
Impact of early life nutrition on growth and intestinal microflora composition in low-birth-weight infants
}

\author{
By Anne Ormisson, Epp Sepp, \\ Urmas Siigur, Heili Varendi and Marika Mikelsaar \\ Received Fehruary 11, 1997; Accepted May 15, 1997
}

\begin{abstract}
We investigated the effect of early life nutrition on growth and intestinal microflora in low-birthweight infants. Eleven preterm newborns (birth weight $1456 \pm 293 \mathrm{~g}$, gestational age $30.6 \pm 1.2$ weeks) received special preterm infant formula as a sole diet from the first enteral feeding until the end of the second month of life (preterm infant formula group (PF group)). Thirteen infants (birth weight $1728 \pm 276 \mathrm{~g}$; gestational age $32.6 \pm 1.4$ weeks) received standard casein-dominant infant formulas available in Estonia (standard formula group (SF group)). Growth parameters were measured at the age of 1,2,3,4 weeks and 2 months. Faecal samples for short chain fatty acids (SCFAs) and bacterial cultures were collected at the age of 6 days and 2 months.

Two results have been received: better growth and better microbial colonization in the group of preterm infant formula. There was significantly higher weight gain in the PF group at the age of 2 months (1814 $\pm 566 \mathrm{~g})$ than in the SF group (1255 $\pm 365 \mathrm{~g})$.

The relative amount of coagulase negative staphylococci was significantly higher in the SF group at the age of 6 days in comparison with the PF group. At the age of 6 days the prevalence of faecal acetic acid was $98 \%$ of total concentration of short chain fatty acids in the PF group and $87 \%$ in the SF group $(\mathrm{p}<0.05)$, which shows the higher prevalence of anaerobic microbes in the PF group. Thus, a nutrient-enriched preterm formula has a positive effect on the intestinal bacterial colonization and growth of low-birth-weight infants.
\end{abstract}

\section{Introduction}

Development of intestinal microflora and respectively the profile of faecal SCFAs, as well as infant growth depend on the food character (breast-feeding, formulafeeding), immunological and environmental factors (1-5). Insufficient contact with the mother and the usual formula feeding have been altering the composition of microflora of preterm neonates: the delayed colonisation with lactobacilli and bifidobacteria, on one hand, and the high counts of opportunistic microorganisms like coagulase negative staphylococci(CONS), enterococci, enterobacteria and candida, on the other hand, have been described. The latter microorganisms are also the most frequent etiological agents of neonatal infections $(6,7)$. The idea of influencing the infants' welfare, e.g. quick weight gain of the newborn through nutrition and intestinal microflora is not a new one $(8,9)$. However, there is a lack of data whether different

Anne Ormisson ${ }^{1}$ Associate Prof., Epp Sepp ${ }^{2}$ MD Master of Science, Urmas Siigur ${ }^{3}$ MD, PhD, Heili Varendi ${ }^{1} \mathrm{MD}$, Marika Mikelsaar ${ }^{2}$ Prof

${ }^{1}$ Dept of Pediatrics, Univ. of Tartu, Tartu, Estonia.

${ }^{2}$ Institute of Microbiology, Univ. of Tartu, Tartu, Estonia.

${ }^{3}$ Laboratory Department, Tartu Univ. Hospital, Tartu, Estonia.

Correspondence: Anne Ormisson, Dept of Pediatrics, Children's Hospital, Univ. of Tartu, Lunini str. 6, EE-2400 Tartu, Estonia. nutrition can influence the health of the preterm infant through microbial ecology.

This study was designed to compare the body weight gain and composition of intestinal microflora and faecal SCFAs of preterm infants receiving different formulas during their first two postnatal months.

\section{Material and Methods}

Subjects

The study was performed in Tartu University Children's Hospital from November 1991 until July 1993. Twenty-four preterm infants (birth weight $<2100 \mathrm{~g}$, gestational age of 28 to 34 weeks), admitted to the neonatal ward were recruited to the study if enteral feeding was introduced within the first days of life and breast milk was not available. Oral informed consent was obtained from the parents and the study was approved by the local Ethics Committee. Of the 24 studied infants, 11 received special preterm infant formula (PF group) (Valio Ltd., Finland) since the first enteral feeding up to the age of 2 months. The remaining 13 infants were fed by standard casein-dominant term formulas (SF group) (Detolakt, Russia) during the same period. The infants were selected for the PF and SF groups according to transferring hospitals. PF group neonates were transferred from Tartu Maternity Hospital (taking care over risk pregnancies and births) which was equipped with preterm infant formula (PF) to be given to the infants from their first enteral feeding The control group (SF group) infants were referred from other maternities that were not equipped with PF. The amount of the formula given to the infants was calculated according to the infants' weight and age needs.

The nutrient composition of PF does not markedly differ from standard formula (SF) in the protein or fat content (Table 1). However, the carbohydrate content was quite different and besides a similar amount of lactose, PF contained maltodextrine. All formulas were fortified with minerals like calcium, phosphorus, iron, and different vitamins (vitamin $\mathrm{E}, \mathrm{C}, \mathrm{B}_{1}$, $\mathrm{B}_{2}, \mathrm{~B}_{6}, \mathrm{~B}_{12}$, folic acid; $\mathrm{SF}$ with and $\mathrm{PF}$ without vitamin $\mathrm{D}$ ).

The clinical characteristics of the studied newborns are presented in Table 2 . All infants were ill and received treatment. Most of the infants received antibiotics either for prevention or treatment of related infections (omphalitis, conjunctivitis; two infants had neonatal septicaemia, no microorganisms were detected in the blood). Parenteral antibacterial therapy (Ampicillin, Gentamycin, followed by Cefotaxim in most cases) in ordinary neonatal doses lasted from 5 days to several weeks. There were no reliable statistical differences in clinical characteristics between the studied groups, except the birth weight with lower figures for the PF group. 
Table 1. Composition of formulas used in the study.

\begin{tabular}{|c|c|c|c|c|c|}
\hline \multirow{2}{*}{$\begin{array}{l}\text { Characteristics } \\
\text { Energy }\end{array}$} & \multirow{2}{*}{$\mathrm{kcal} / 100 \mathrm{ml}$} & \multicolumn{2}{|c|}{ Preterm infant formula } & \multicolumn{2}{|l|}{ Standard formula } \\
\hline & & 80 & & 67 & \\
\hline Protein & $\mathrm{g} / 100 \mathrm{ml}$ & $\begin{array}{l}2.0 \\
\text { whey } \\
\text { casein }\end{array}$ & $\begin{array}{l}1.0 \\
1.0\end{array}$ & $\begin{array}{l}1.8 \\
\text { casein based }\end{array}$ & \\
\hline Lipids & $\mathrm{g} / 100 \mathrm{ml}$ & $\begin{array}{l}3.8 \\
\text { linoleic acid }\end{array}$ & 0.5 & $\begin{array}{l}3.5 \\
\text { unsaturated fat }\end{array}$ & 0.8 \\
\hline Carbohydrates & $\mathrm{g} / 100 \mathrm{ml}$ & $\begin{array}{l}9.6 \\
\text { lactose } \\
\text { maltodextrine }\end{array}$ & $\begin{array}{l}7.3 \\
2.3\end{array}$ & $\begin{array}{l}7.0 \\
\text { lactose }\end{array}$ & 7.0 \\
\hline $\begin{array}{l}\text { Minerals } \\
\text { phosphor } \\
\text { calcium } \\
\text { ferrum } \\
\mathrm{Ca}: \mathrm{P}\end{array}$ & & $\begin{array}{l}38 \mathrm{mg} \% \\
55 \mathrm{mg} \% \\
1.2 \mathrm{mg} \% \\
1.6\end{array}$ & & $\begin{array}{l}40 \mathrm{mg} \% \\
58 \mathrm{mg} \% \\
1.2 \mathrm{mg} \% \\
1.5\end{array}$ & \\
\hline
\end{tabular}

Table 2. Characteristics of the study groups.

\begin{tabular}{lcc}
\hline Characteristics & $\begin{array}{c}\text { PF group } \\
\mathrm{n}=11\end{array}$ & $\begin{array}{c}\text { SF group } \\
\mathrm{n}=13\end{array}$ \\
\hline Gestational age, weeks, mean $\pm \mathrm{SD}$ & $30.6 \pm 1.2$ & $32.6 \pm 1.4$ \\
Birth weight, g, mean \pm SD & $1456 \pm 294$ & $1731 \pm 281^{*}$ \\
Hospital stay, weeks, median (range) & $6(3-11)$ & $6(3-10)$ \\
Diagnoses (no of infants) & & 1 \\
septicaemia & 1 & 4 \\
IRDS & 4 & 2 \\
asphyxia & 2 & 2 \\
hyperbilirubinaemia & 5 & $9(69 \%)$ \\
related infections & 2 & 4 \\
No (\%) treated with ab & $11(100 \%)$ & 5 \\
without ab & 0 & 4 \\
one to three ab & 7 & 7 \\
more than three ab & 4 & \\
Mechanical lung ventilation & 5 & \\
& & \\
\hline
\end{tabular}

$* \mathrm{p}<0.05 ;$ IRDS = idiopathic respiratory distress syndrome; $\mathrm{ab}=$ antibiotics

$\mathrm{PF}=$ preterm infant formula; $\mathrm{SF}=$ standard formula

Table 3. Growth of PF and SF group preterm infants during the first 2 months of life.

\begin{tabular}{lcc}
\hline & $\begin{array}{c}\text { PF group } \\
\mathrm{n}=11\end{array}$ & $\begin{array}{c}\text { SF group } \\
\mathrm{n}=13\end{array}$ \\
\hline $\begin{array}{l}\text { Minimum relative weight } \\
\text { (\% of birth weight) }\end{array}$ & \\
$\begin{array}{l}\text { Regained weight } \\
\quad \text { (age in days) }\end{array}$ & 93 & 92 \\
$\begin{array}{l}\text { Relative body weight, mean } \pm \mathrm{SD} \\
\text { (\% of birth weight) }\end{array}$ & 10 & 12 \\
1 week & & \\
2 weeks & $96 \pm 5$ & $96 \pm 8$ \\
3 weeks & $107 \pm 9$ & $102 \pm 8$ \\
4 weeks & $117 \pm 12$ & $109 \pm 7$ \\
2 months & $132 \pm 13$ & $123 \pm 14$ \\
Body weight gain, $\mathrm{g}$ & $226 \pm 36$ & $174 \pm 22 *$ \\
$\quad$ by 4 weeks & & \\
by 2 months & $463 \pm 181$ & $368 \pm 195$ \\
& $1815 \pm 566$ & $1255 \pm 364 *$ \\
\hline
\end{tabular}

$* \mathrm{p}<0.05 ; \mathrm{PF}=$ preterm infant formula; $\mathrm{SF}=$ standard formula
Growth data

Body weight was measured on a commercial balance beam scale (to the nearest $10 \mathrm{~g}$ ), body length was measured on a measuring board with a sliding footboard and head circumference by measuring tape (both to the nearest $0,5 \mathrm{~cm}$ ) at the age of $1,2,3,4$ and 8 weeks.

\section{Specimen collection}

Faecal samples for bacterial cultures and short chain fatty acids were collected at the age of 6-7 days and 2 months. Approximately $1 \mathrm{~g}$ of voided stool was collected into sterile plastic containers by ward staff and later by the parents of the participating infants. In the hospital it was immediately taken to the laboratory. At home the samples were put into a domestic refrigerator $\left(-4^{\circ} \mathrm{C}\right)$ until taken on the same day to the laboratory for study. In the laboratory the samples were kept at $-20^{\circ} \mathrm{C}$ until the time of analysis.

\section{Bacteriological}

studies methods

The quantitative composition of faecal microflora was estimated: S.aureus, CONS, Streptococci, Enterococci, Lactobacilli, Enterobacteria, Candida, Bifidobacteria, Anaerobic cocci, Clostridia, Bacteroides $(10,11)$.

The weighed samples of faeces were serially diluted under a stream of $\mathrm{CO}_{2}$ in prereduced phosphate buffer $(\mathrm{pH} \mathrm{7,2)}$. The faecal concentrations of bacteria (log $\mathrm{CFU} / \mathrm{g}$ ) were determined by seeding the serial dilutions on seven different freshly prepared media: FAST agar (Lab M) for total anaerobes, egg-yolk medium for clostridia, MRS agar (Merck) for lactobacilli and streptococci, yeast-extract agar for total aerobes, yeast-extract agar with 6,5 per cent of sodium chloride for staphylococci, Endo agar for coliforms, Sabouraud medium supplemented with penicillin $(50000 \mathrm{u} / \mathrm{l})$ and streptomycin $(40000 \mathrm{u} / \mathrm{l})$ for yeasts.

The yeast-extract agar, salt-yeastextract agar, Endo medium and Sabouraud medium were incubated for 48 hrs aerobically at $37^{\circ} \mathrm{C}$ and inspected after 24 and $48 \mathrm{hrs}$. MRS medium was incubated in 10 per cent $\mathrm{CO}_{2}$ atmosphere for $72 \mathrm{hrs}$. FAST for anaerobes was incubated for up to 4-5 days in an anaerobic container with the mixture of gases $\left(\mathrm{N}_{2}-85 \%, \mathrm{CO}_{2}-10 \%\right.$, $\mathrm{H}_{2}-5 \%$ ). The number of colonies from the last two emerging growth dilutions on different media were counted. The lower limit of detection was $10^{3}$ microorganisms/g of faeces. After the identification of the bacteria (12), their counts $(\log \mathrm{cfu} / \mathrm{g}$, in faeces and frequency of occurrence $(\%$, in the study groups were calculated. 
Table 4. Differences in faecal flora of preterm infants at the age of 6 days and 2 months ( log cfu/g and frequency of occurrence - \%).

\begin{tabular}{|c|c|c|c|c|c|c|c|c|}
\hline \multirow[t]{2}{*}{ Microorganisms } & \multirow[t]{2}{*}{ Age } & \multicolumn{4}{|c|}{ PF group } & \multicolumn{3}{|c|}{ SF group } \\
\hline & & Median & & Range & $\begin{array}{l}\% \text { of infants } \\
\text { colonised }\end{array}$ & Median & Range & $\begin{array}{c}\% \text { of infants } \\
\text { colonised }\end{array}$ \\
\hline \multirow[t]{2}{*}{ Total aerobes } & $6 d$ & 10.2 & & $8.1-11.7$ & 100 & 9.6 & $6.4-11.7$ & 100 \\
\hline & $2 \mathrm{~m}$ & 7.9 & & $5.6-10.1$ & 100 & 10.9 & $8.6-11.6$ & 100 \\
\hline \multirow[t]{2}{*}{ S.aureus } & $6 \mathrm{~d}$ & 0 & & $0-8.3$ & 17 & 0 & $0-5.1$ & 8 \\
\hline & $2 \mathrm{~m}$ & 0 & & $0-4.6$ & 14 & 4.3 & $0-7.3$ & 60 \\
\hline \multirow[t]{2}{*}{ CONS } & $6 \mathrm{~d}$ & 0 & $* *$ & $0-10.6$ & $42 * *$ & $6.6 * *$ & $0-9.9$ & $100 * *$ \\
\hline & $2 \mathrm{~m}$ & 4.6 & & $0-7.8$ & 57 & 5.3 & $0-10.6$ & 60 \\
\hline \multirow[t]{2}{*}{ Streptococci } & $6 \mathrm{~d}$ & 9.1 & & $0-11.4$ & $58 *$ & 0 & $0-11.3$ & $39 *$ \\
\hline & $2 \mathrm{~m}$ & 4.8 & & $0-9.3$ & 57 & 5.3 & $0-11.6$ & 60 \\
\hline \multirow[t]{2}{*}{ Enterococci } & $6 \mathrm{~d}$ & 0 & & $0-11.6$ & 33 & 5.14 & $0-11.7$ & 54 \\
\hline & $2 \mathrm{~m}$ & 3.8 & & $0-7.6$ & 57 & 8.3 & $0-10.6$ & 60 \\
\hline \multirow[t]{2}{*}{ Lactobacilli } & $6 \mathrm{~d}$ & 0 & & $0-8.3$ & 17 & 0 & $0-7.3$ & 23 \\
\hline & $2 \mathrm{~m}$ & 4.3 & & $0-7.3$ & 57 & 7.8 & $0-11.1$ & 60 \\
\hline \multirow[t]{2}{*}{ Enterobacteria } & $6 \mathrm{~d}$ & 8.3 & & $0-11.4$ & 68 & 7.1 & $0-11.2$ & 69 \\
\hline & $2 \mathrm{~m}$ & 0 & $* * *$ & $0-6.3$ & $29 *$ & $8.6 * * *$ & $6.8-11.4$ & $100 *$ \\
\hline \multirow[t]{2}{*}{ Candida } & $6 \mathrm{~d}$ & 0 & & $0-10.7$ & 33 & 4.3 & $0-11.6$ & 54 \\
\hline & $2 \mathrm{~m}$ & 0 & $* * *$ & $0-5.3$ & $29 *$ & $6.6 * * *$ & $4.6-8.6$ & $100 *$ \\
\hline \multirow[t]{2}{*}{ Total anaerobes } & $6 \mathrm{~d}$ & 10.3 & & $0-12.0$ & 92 & 8.9 & $0-11.8$ & 92 \\
\hline & $2 \mathrm{~m}$ & 7.8 & & $5.6-10.7$ & 100 & 10.3 & $9.0-11.1$ & 100 \\
\hline \multirow{2}{*}{ Bifidobacteria } & $6 \mathrm{~d}$ & 0 & & $0-11.0$ & 17 & 0 & 0 & 0 \\
\hline & $2 \mathrm{~m}$ & 0 & & $0-7.4$ & 29 & 0 & $0-8.6$ & 0 \\
\hline \multirow[t]{2}{*}{ Anaerobic cocci } & $6 \mathrm{~d}$ & 0 & & $0-11.3$ & 42 & 0 & $0-10.3$ & 46 \\
\hline & $2 \mathrm{~m}$ & 0 & & $0-10.7$ & 43 & 10.3 & $0-12.0$ & 80 \\
\hline \multirow[t]{2}{*}{ Clostridia } & $6 \mathrm{~d}$ & 0 & & 0 & 0 & 0 & $0-7.3$ & 30 \\
\hline & $2 \mathrm{~m}$ & 0 & & $0-5.3$ & 29 & 0 & 0 & 0 \\
\hline \multirow[t]{2}{*}{ Bacteroides } & $6 \mathrm{~d}$ & 8.2 & & $0-11.5$ & 68 & 8.14 & $0-11.8$ & 77 \\
\hline & $2 \mathrm{~m}$ & 7.0 & & $0-8.3$ & 86 & 6.9 & $0-11.1$ & 60 \\
\hline
\end{tabular}

$\mathrm{PF}=$ preterm infant formula; $\mathrm{SF}=$ standard formula; 6 days $: \mathrm{PF}$ group: $\mathrm{n}=11 ;$ SF group: $\mathrm{n}=13 ; 2$ months: PF group: $\mathrm{n}=7 ; \mathrm{SF}$ group: $\mathrm{n}=5$ $* \mathrm{p}<0.05 ; * * \mathrm{p}<0.01 ; * * * \mathrm{p}<0.001$

\section{SCFAs measurements}

The samples were thawed at room temperature and the aliquots $(0.4-0.6 \mathrm{~g})$ homogenised in $2 \mathrm{ml}$ of distilled water containing $3 \mathrm{mmol} / \mathrm{l}$ of aethylbutyric acid as internal standard and $0.5 \mathrm{ml}$ of $\mathrm{H}_{2} \mathrm{SO}_{4}(0.5 \mathrm{mmol} / \mathrm{l})$. The homogenate was vacuum-distilled and analysed for SCFAs as described by Zijlstra with modifications by Hoverstad (13). Chromatograms were recorded, peak areas determined and concentrations calculated with the Shimadzu Data Processor Chromatopac C-R3A.

\section{Statistics}

Wilcoxon's rank sum test for paired data and Mann-Whitney's rank sum test for unpaired data, Student's t-test and Fisher's exact test for comparing the groups and Kendall rank correlation analyses for discrete data were used. For comparison of members of staphylococci and streptococci in different types of feeding the Spearman nonparametric correlation index was calculated.

\section{Results}

\section{Infants' growth}

Changes in body weight of preterm infants during the first 2 months of life are presented in Table 3. The infants of the PF group had statistically significant $(\mathrm{p}<0.03)$ lower birth weight than the infants of the SF group.

The weight loss did not differ and the infants of both groups regained birth weight within 10-12 days.

There were no reliable differences in the increase of body weight within the first month of life. At the age of 2 months body weight gain was significantly higher in the $\mathrm{PF}$ group than in the SF group $(\mathrm{p}<0.05)$. At the age of 2 months body weight of the PF group was $226 \pm 36 \%$ of their birth weight and in the SF group it was only $174 \pm 22 \%$ $(p<0.001)$. Increase of the other growth parameters (head circumference, body length) didn't show differences (data not shown). All infants studied had anaemia of prematurity at the age of 2 months. There were no differences found in the mean haemoglobin values nor in the count of erythrocytes between the studied groups (data not shown).

\section{Bacteriological data}

At the end of the first week of life the intestinal tract of all preterm newborns was colonised with aerobes and their counts varied in wide ranges, Table 4 . The majority of newborns were also colonised with anaerobes, only one newborn in both groups did not show colonisation with any anaerobes investigated. We could rarely trace bifidobacteria and lactobacilli in studied newborns. Concerning opportunistic microorganisms the intestinal tract of infants of the PF group was more rarely colonised with CONS in comparison with the infants of the SF group. Also the counts of CONS $(\log \mathrm{cfu} / \mathrm{g})$ in the PF group were in a lower level than those of the SF group. There was noticed a tendency that streptococci had been more frequently colonizing the newborns of the PF group. At the same time there was a significant negative correlation between the occurrence of CONS and streptococci in both groups at the age of 6 days $(r=0.5546, n=24, p<0.03)$.

At the end of the second month of life all the observed infants were colonised with aerobic and anaerobic microorganisms. The frequency of occurrence of enterobacteria and candida was increased in infants fed by SF compared to the infants of the PF group.

\section{Faecal short chain fatty acids}

The SCFAs' profiles did not differ between the PF and SF groups as a whole at the age of 6 days and 2 month, Table 5. In the analyses of individual fatty acids 
Table 5. Total concentration of faecal SCFAs $(\mathrm{mmol} / \mathrm{kg})$ and relative contribution of acetic acid and propionic acid (\%) at the age of 6 days and 2 months in preterm infants of PF group and SF group. Median and ranges are given.

\begin{tabular}{|c|c|c|c|c|c|}
\hline & \multicolumn{2}{|c|}{6 days } & & \multicolumn{2}{|c|}{2 months } \\
\hline & $\begin{array}{l}\text { PF group } \\
n=10\end{array}$ & $\begin{array}{l}\text { SF group } \\
n=11\end{array}$ & & $\begin{array}{l}\text { PF group } \\
n=7\end{array}$ & $\begin{array}{l}\text { SF group } \\
n=9\end{array}$ \\
\hline Total & $\begin{array}{l}20.2 \\
(7.7-29.6)\end{array}$ & $\begin{array}{l}17.0 \\
(2.6-54.2)\end{array}$ & & $\begin{array}{l}67.6 \\
(13.3-112.8)\end{array}$ & $\begin{array}{l}36.5 \\
(17.2-75.9)\end{array}$ \\
\hline Acetic acid & $\begin{array}{l}98.0 \\
(94.8-100)\end{array}$ & $\begin{array}{l}87.6 \\
(49.3-100)\end{array}$ & $*$ & $\begin{array}{l}73.1 \\
57.9-97.1)\end{array}$ & $\begin{array}{l}79.2 \\
(71.3-96.6)\end{array}$ \\
\hline Propionic acid & $\begin{array}{l}2.0 \\
0-4.5\end{array}$ & $\begin{array}{l}7.0 \\
0-36.6\end{array}$ & $*$ & $\begin{array}{l}10.7 \\
2.7-36.9\end{array}$ & $\begin{array}{l}13.0 \\
2.6-24.9\end{array}$ \\
\hline
\end{tabular}

SCFAs = short chain fatty acids $; \mathrm{PF}=$ preterm infant formula; $\mathrm{SF}=$ standard formula $* \mathrm{P}<0.05$

significant differences were found in acetic and propionic acid concentration. The prevalence of acetic acid was significantly higher in the PF group in the samples taken at 6 days $(\mathrm{p}<0.05)$ and the prevalence of propionic acid was significantly lower $(\mathrm{p}<0.05)$. No differences were found in the concentration of acetic and propionic acids at the age of two months between the studied groups.

\section{Discussion}

Feeding of preterm infants with PF resp. $\mathrm{SF}$ resulted in significant differences regarding growth and intestinal microbial colonisation. There was a considerably better weight gain since the age of 2 weeks in the PF group, becoming significant at 2 months of age. This finding seems to be even more remarkable if we accept that the starting point of children fed by PF was worse, while their gestational age and body weight at birth were significantly lower, as they were born in the IIIrd level maternity hospital. Yet the investigated groups did not differ significantly in duration of hospital stay, clinical diagnoses/ symptoms and duration and mode of antibacterial treatment. Since the duration of treatment as well as the combination of antibiotics used was not completely identical, influence of the treatment on the

\section{References}

1. Heine WE, Mohr C, Wutzke KD: Host-microflora correlations in infant nutrition. Progress in Food and Nutrition science 1992;16:181-97.

2. Zetterström R, Bennet R, Nord KE: Early infant feeding and micro-ecology of the gut. Acta Paed Jap 1994;36:562-71.

3. Mändar $\mathrm{R}$, Mikelsaar $\mathrm{M}$ : Transmission of mother's microflora to the newborn at birth. Biol Neonate 1996;69:30-5.

4. Ahtonen P: Microbial colonization of newborn infants. Dissertation. Turku, 1994

5. Siigur U, Ormisson A, Tamm A: Faecal shortchain fatty acids in breast-fed and bottle-fed infants. Acta Paediatr 1993;82:536-8. results cannot be excluded.

The better weight gain of preterm infants under feeding with PF has been described by several authors $(9,14)$. It might be caused by the nutritional differences (different quantitative and qualitative content of carbohydrates) between the formulas themselves as well as by advances in microflora composition.

We observed major disturbances in microbial ecology of intestinal tract in preterm infants treated with antibiotics and undergone intensive care procedures, not receiving breast milk. There was found an imbalance of the quantitative composition of intestinal microflora in both groups in the first week of life, expressed as a rare colonisation by bifidobacteria and lactobacilli and frequent occurrence and high counts of bacteroides and enterobacteria. Absence in attaining of bifidobacterial flora in both groups is probably related to the fact that breast milk was not used. Anyway, on postnatal day 6 the concentration of faecal acetic acid was significantly higher in the PF group indicating the higher content of anaerobic flora.

At the age of 2 months the infants of the SF group showed an increase in colonisation with enterobacteria and Candida spp. unlike those of the PF group. The

6. el-Mohandes AE, Keiser JF, Johnson LA, Refat $\mathrm{M}$, Jackson BJ: Aerobes isolated in faecal microflora of infants in the intensive care nursery: relationship to human milk use and system sepsis. Am J Infect Control 1993;21:231-4.

7. Kloos WE, Bannerman TL: Update on clinical significance of coagulase-negative staphylococci. Clin Micr Rev 1994; 7:117-40.

8. Gothefors L: Effects of diet on intestinal flora Acta Paediatr Scand 1989;351:118-21.

9. Morley R, Lucas A: Influence of early diet outcome in preterm infants. Acta Paediatr 1996 Suppl 405:123-6

10. Sepp E, Mikelsaar M, Salminen S: Effect of administration of Lactobacillus casei strain GG frequent occurrence of CONS, enterococci, streptococci, Candida spp. and enterobacteria as important opportunistic pathogens for neonates has been shown also in previous studies of preterm infants nursed in hospital milieu $(6,7)$. Thus, the preterm infants fed by PF showing low colonisation by CONS and enterococci might have had some advantage over the others fed by SF.

The investigated infants fed by $\mathrm{PF}$ showed the increased occurrence of lactic acid producing streptococci compared to the SF group. It can be speculated that the high content of maltodextrine in PF serves as useful substrate for lactic acid producing streptococci. Some Leuconostoc spp. among streptococci are able to ferment dextranes to maltose (12). Putative low $\mathrm{pH}$ of intestinal tract may create intestinal milieu more similar to it in breast fed infants. The acidic environment may suppress the opportunistic pathogens as enterobacteria and candida and stand for more balanced microecology of gut $(4,14)$.

Thus, we have demonstrated the possibility of influencing growth of preterm infant and intestinal microflora composition by using special preterm infant formula. Reduction of the load of such potentially pathogenic microorganisms as CONS, enterococci, enterobacteria and Candida spp. in the intestine of preterm infants kept under intensive antibacterial treatment during their first weeks of life is worth special nutritional intervention.

\section{Acknowledgements}

This study was supported by the grant no 23 from Estonian Science Foundation and was a part of research which has been awarded with Scientific Prize of the Republic of Estonia in 1994. The authors would like to thank Ms Marja Kahra, Lic Phil, Valio, Helsinki and Valio Ltd. for the supply of preterm infant formula. We would like to express appreciation to Dr Lea Maipuu, Dr Piret Külasepp and nurse Jana Retpap for their assistance and to Prof. Hans K. Akerblom for helpful advice.

on the gastrointestinal microbiota of newborns. Micr Ecol in Health and Disease 1993;6:309-14.

11. Mikelsaar M, Siigur U: Metronidazole and the intestinal microecology of rats. Micr Ecol in Health and Disease 1992;5:139-46.

12. Balows A, Hausler WJ, Herrmann KL et al, eds Manual of Clinical Microbiology. Fifth edition. Washington, 1991.

13. Hoverstad T, Fausa O, Bjorneklett A, Bohmer T: Short-chain fatty acids in the normal human faeces. Scand J Gastroenter 1984;19:375-81.

14. Yoshioka H, Iseki K, Fujita K. Development and differences of intestinal flora in neonatal period in breast-fed and bottle-fed infants Pediatrics 1983;72:317-21. 